Journal of Business Management Review

homepage : https://profesionalmudacendekia.com/index.php/jbmr

\title{
Exploring Determinants of Entrepreneurial Readiness on Sukses Berkah Community's Member
}

\author{
Arik Wulandari ${ }^{*}$
}

Agus Hermawan ${ }^{2}$

Imam Mukhlis ${ }^{3}$

1Program Study of Business and Management Education, Faculty of Economics and Business, Universitas Negeri Malang, Indonesia

2Department of Management, Faculty of Economics and Business, Universitas Negeri Malang, Indonesia

${ }^{3}$ Department of Economic Development, Faculty of Economics and Business, Universitas Negeri Malang, Indonesia

\begin{tabular}{ll}
\hline ARTICLE INFO & ABSTRACT \\
\hline ISSN: & $\begin{array}{l}\text { This article aims to determine (1) the effect of motivation, opportunity } \\
\text { identification, resources, and entrepreneurial abilities on entrepreneurial } \\
\text { readiness; and (2) the role of entrepreneurship training as a moderating } \\
\text { variable on motivation, opportunity identification, resources, and }\end{array}$ \\
Motivation; Opportunity & $\begin{array}{l}\text { entrepreneurial abilities on entrepreneurial readiness. This research is a } \\
\text { quantitative study using proportional random sampling with a total of } 200\end{array}$ \\
Identification; Resources; & respondents. Data collection used a questionnaire whose results analyze by \\
Entrepreneurial Ability; & $\begin{array}{l}\text { Moderated Regression Analysis (MRA). The results showed a positive and } \\
\text { Entrepreneurship Training. } \\
\text { significant effect of motivation, opportunity identification, resources, } \\
\text { entrepreneurial ability, and entrepreneurship training that could moderate } \\
\text { the impact of all these factors on entrepreneurial readiness. Based on this } \\
\text { research results, it can know that to start entrepreneurship requires the } \\
\text { motivation to exert all efforts, opportunity identification to find and } \\
\text { implement potential in business, resources to increase competitive business } \\
\text { advantage, and entrepreneurial ability to achieve business success using all } \\
\text { its capabilities. Entrepreneurship training can improve these factors. The } \\
\text { better the entrepreneurship training follows, the more positive impact on } \\
\text { improving the readiness to start a thriving Sukses Berkah Community (SBC) } \\
\text { member. }\end{array}$ \\
\hline
\end{tabular}

\section{Introduction}

Unemployment and poverty are still problems for Indonesia. The increasing number of Indonesia's population who enter the world of work every year is a challenge for the Indonesian state to provide employment opportunities. The current lack of employment opportunities cannot accommodate the large number of Indonesians who wish to work. The high population and few employment

Journal of Business and Management Review Vol. 2 No. 42021 Page 303-317

DOI: $10.47153 /$ jbmr24.1332021

*Corresponding Author

Email address: arik.wulandari.1904158@student.um.ac.id 
opportunities will also create fierce competition for the world of work, and many educated people are unemployed because of difficulties in getting jobs. A reasonably high unemployment rate occurs among young workers in the age range 15-24 years (Badan Pusat Statistik, 2020). This problem occurs because of a person's lack of courage to take a high-risk job such as entrepreneurship. A statement from the United Nations (UN) explained that a country should ideally have entrepreneurs of at least $2 \%$ of the total population. However, in reality, the number of unemployed people in Indonesia is still relatively high, namely recorded in February 2020 as much as $4.99 \%$ of Indonesia's population, amounting to 267.7 million (Badan Pusat Statistik, 2020). Therefore, a change is needed to overcome this by becoming an entrepreneur. As is the case, according to Sudrajat (2012), entrepreneurship is one solution to reduce the number of unemployed in Indonesia.

Fostering an entrepreneurial attitude in society is very important and is a strategic step in developing qualified Indonesian human resources to create their businesses. Alma (2011) explains that entrepreneurship can see opportunities that then form an effort to take and take advantage of these opportunities. By doing entrepreneurship, people do not depend on jobs but can create new jobs for themselves and others. The first step that can take is to encourage the entrepreneurial readiness of the community.

Entrepreneurial readiness is very influential in growing the number of entrepreneurs in society. With entrepreneurial readiness, a person can take action with various risks in the future. Entrepreneurial readiness is a collection of attitudes and skills needed for entrepreneurship in any condition (Pratomo et al., 2018). Thus entrepreneur can exert their ability to be courageous and need self-achievement (Olugbola, 2017). Based on this definition, it can conclude that to form entrepreneurial readiness, motivation, ability to identify opportunities, resources, and entrepreneurial ability are needed.

Motivation is a factor that influences a person to carry out an activity that has a purpose (Oktiani, 2017). High motivation must exist in an entrepreneur because motivation will foster a strong mentality to excel in doing a job. Someone is ready to create a new business by looking for opportunities, analyzing advanced industries, and evaluating opportunities using market demand data (Hayton et al., 2011). Business opportunities encourage the emergence of a person's desire for entrepreneurship. Entrepreneurs need resources to create competitive value in the new business they have found, ultimately supporting the business's success and performance (Huang, 2016). Good resources will affect production results, creating high and useful product or service values to compete and increase entrepreneurial performance (output). To start a business also requires a variety of abilities both for the entrepreneur himself or for his employees. Entrepreneurial ability is the characteristics, traits, insights, and skills that become someone's provision for entrepreneurship and managing everything related to the task carried out to run effectively (Lorena, 2018). 
The factors forming entrepreneurial readiness need to cultivate in society by providing entrepreneurial insight, one of which is through entrepreneurship training activities. Entrepreneurship training can carry out through formal or non-formal education such as business seminars or the business community. Sukses Berkah Community (SBC) is a business community that carries out entrepreneurship training and learning. SBC is a forum for entrepreneurs and anyone who wants to become entrepreneurs with entrepreneurship learning and training according to Islamic law teachings. It has various business service programs such as training, coaching, consulting, and mentoring (Sukses Berkah Community, 2020).

This research conduct on the Sukses Berkah Community (SBC) members, where aspiring entrepreneurs and entrepreneurs have been active since 2016. SBC provides mentoring programs, namely the Business Assistance Group (KPB), One Year Coaching (OYC), Quantum Leap Program (QLP), and Turn Around Program (TAP). However, entrepreneurship training activities carried out in this community have not provided a complete overview of whether entrepreneurship training is genuinely able to shape its members' entrepreneurial readiness and what factors influence the formation of entrepreneurial readiness.

Research conducted by Kallas (2019) shows a positive and significant effect of motivation on entrepreneurial readiness. Research by Khin \& Lim (2018) states that opportunity identification contributes to the readiness to set up a business and supports business success. Research by Vuong et al. (2015) shows that resource factors and social networks have a significant effect on starting a business. Research by Seun \& Kalsom (2015) states that entrepreneurial ability has a positive and significant effect on creating new businesses. Research conducted by Alam et al. (2019) shows that entrepreneurship training can increase new entrepreneurs because it can increase entrepreneurial motivation. Research by Baggen et al. (2018) states that entrepreneurship training can form the ability to identify business opportunities. Research conducted by Ahmed et al. (2020) shows that entrepreneurship training has a positive effect on resource management so that it supports the readiness to start a business. Research by Ho et al. (2018) states that entrepreneurship training is an effective way of shaping entrepreneurial ability to increase entrepreneurial readiness. This study aims to determine the effect of motivation, identification of opportunities, resources, and entrepreneurial abilities on entrepreneurial readiness and the role of entrepreneurship training as a moderating variable for the impact of these factors on entrepreneurial readiness.

\section{Literature Review}

\section{Motivation}

Motivation is a power within a person in the form of feelings and begins with a response to certain goals. To make someone have entrepreneurial readiness, the most important thing is haste, desire to be independent, and profit (Choo \& Wong, 2006). Saiman (2009) explains that a person's motivation to be entrepreneurial is to earn 
profits, freedom of individual dreams, and independence. An entrepreneur will be motivated by many factors. So, the indicators of entrepreneurial motivation variables include achievement motive, desire for independence, and profit motivation.

\section{Opportunity Identification}

According to Suharyono (2017), an entrepreneur is someone free to determine and run his own business and take advantage of opportunities to develop his business. Ability to identify opportunities related to new, valuable, legal, and prospective ideas. Good opportunities should be by one's abilities, desire to carry out certain activities, goals, experience, and business knowledge. Hunter (2013) states that opportunities depend on someone easy to know, forming concepts that can become ideas. Olugbola (2017) argues that several factors affect a person's ability to identify opportunities, including knowledge, social networks, and cognitive skills. However, creative and innovative ideas are also needed to determine ideas that can maximize existing opportunities. So, the indicators of the opportunity variable include innovative ideas, creative ideas, social networks, and previous knowledge.

\section{Resources}

Resources are assets used by entrepreneurs to support their business activities. Every business must produce and offer products or services of sale value, so the product can dominate the market and strengthen relationships with customers for profit. The source of a product/service's superiority in a sustainable manner is a resource that has value, is scarce, cannot easily be imitated, and has no substitute. To obtain primary resources can be through leasing or main partners. The main resources include physical, intellectual, and financial resources (Osterwalder \& Pigneur, 2012). Therefore, indicators to measure resources variables include intellectual property (intellectual resources), physical resources (physical resources), and access to finance (financial resources).

\section{Entrepreneurial Ability}

Entrepreneurial ability is a skill (skill), knowledge, attitude, and level of emotional maturity, is an entrepreneur in starting and running a business. Entrepreneurial ability is very important to improve performance, which means the extent to which a business can achieve optimal results based on its capabilities. Olugbola (2017) also explains that entrepreneurial skills are needed so that administrative activities run well when starting a new business. There are three skills: technical skills, management skills, entrepreneurial skills, and personal maturity skills (Chang \& Rieple, 2013). Therefore, indicators to measure entrepreneurial ability variables include managerial ability, financial capability, marketing ability, business planning, team building ability, and business administration skills.

\section{Entrepreneurship Training}


Entrepreneurship training is training that is carried out to train someone to have entrepreneurial skills so that they can create a business appropriately by using existing opportunities and providing job opportunities both for themselves and for others. Sitorus (2015) explains that entrepreneurship training aims to broaden participants' insights and expertise in entrepreneurship and shape the technical abilities of participants. Pandian (2019) explains that several factors affect the success of entrepreneurship training, namely training material, the role of the trainer, training methods, training facilities, and the characteristics of training participants. Referring to this explanation, the indicators of entrepreneurial training variables include training material, the role of the trainer, training methods, training facilities, and characteristics of training participants.

\section{Entrepreneurial Readiness}

Entrepreneurship readiness is the willingness and desire of individuals to respond to business activities by utilizing their knowledge. Entrepreneurial ability can support business success, a person's attractiveness to become an entrepreneur, and a person's willingness to continue to develop their knowledge. The characteristics of entrepreneurial readiness are thinking rationally, critically, and objectively, having expertise and willingness to work with others, completing tasks optimally, being responsible, easily adapting to technological developments, and updating information (Fitriyanto, 2006). Referring to this explanation, the indicators of entrepreneurial readiness include intention, ability, learning (willingness to continue learning), and attractiveness (attractiveness to become entrepreneurs).

\section{Method}

This study uses a quantitative approach. The population of this study is all members of the Sukses Berkah Community, amounting to 378 members. The sampling technique used was proportional random sampling, with a total sample size of 200 members of Sukses Berkah Community (SBC). The instrument used to measure motivation was adapted from Olugbola (2017) using 7 items. Opportunity identification adapted from Olugbola \& Kalsom (2015) using 11 items. Resources adapted from Olugbola (2017) using 8 items. Entrepreneurial ability was adapted from Olugbola (2017) using 17 items. Entrepreneurship training adapted from Pandian (2019) using 16 items. And entrepreneurial readiness was adapted from Halim et al. (2017) using 11 items. The questionnaire was distributed to 200 SBC members. The research model presented in Figure 1. Data analysis performed using Moderated Regression Analysis using Statistical Package for Social Sciences (SPSS) 20, the research equation model as follows:

$$
Y=a+\beta_{1} X_{i}+\beta_{3} X_{i} * Z_{I}+e
$$

Figure 1. Research Equation Model 


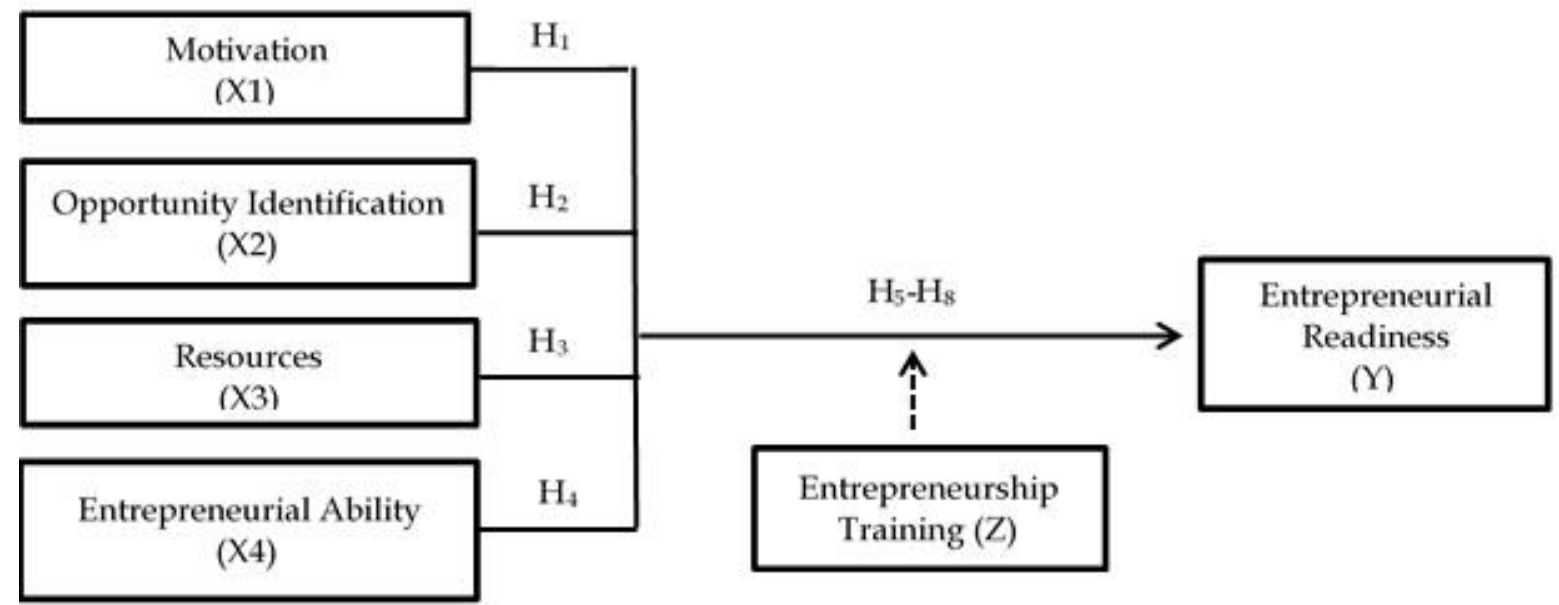

Figure 1. Research Model

\section{Results \& Discussion}

Following are the results of the Moderated Regression Analysis (MRA) test using SPSS 20. The value of R Square and the partial test results (t-test) presented in Table 3.

Table 1. Value of R Square

\begin{tabular}{|c|c|c|c|c|}
\hline \multirow[b]{2}{*}{ Equation } & \multicolumn{2}{|c|}{$\begin{array}{l}\text { Coefficient } \\
\text { Determination }\end{array}$} & \multicolumn{2}{|c|}{ Partial Test } \\
\hline & R Square & $\begin{array}{l}\text { nination } \\
\text { Adjusted R } \\
\text { Square }\end{array}$ & B & Sig. \\
\hline $\begin{array}{l}\text { Motivation to entrepreneurial } \\
\text { readiness }\left(\mathrm{H}_{1}\right)\end{array}$ & 0,089 & 0,085 & 0,368 & 0,000 \\
\hline $\begin{array}{l}\text { Opportunity identification to } \\
\text { entrepreneurial readiness }\left(\mathrm{H}_{2}\right)\end{array}$ & 0,210 & 0,206 & 0,433 & 0,000 \\
\hline $\begin{array}{l}\text { Resources to entrepreneurial } \\
\text { readiness }\left(\mathrm{H}_{3}\right)\end{array}$ & 0,125 & 0,121 & 0,305 & 0,000 \\
\hline $\begin{array}{l}\text { Entreprenurial ability to } \\
\text { entreprenurial readiness }\left(\mathrm{H}_{4}\right)\end{array}$ & 0,076 & 0,071 & 0,101 & 0,000 \\
\hline $\begin{array}{l}\text { Entrepreneurship training } \\
\text { strengthens the effect of } \\
\text { motivation on entrepreneurial } \\
\text { readiness }\left(\mathrm{H}_{5}\right)\end{array}$ & 0,126 & 0,112 &,- 006 & 0,723 \\
\hline $\begin{array}{l}\text { Entrepreneurship training } \\
\text { strengthens the effect of } \\
\text { opportunity identification on } \\
\text { entrepreneurial readiness }\left(\mathrm{H}_{6}\right)\end{array}$ & 0,244 & 0,232 & 0,019 & 0,007 \\
\hline $\begin{array}{l}\text { Entrepreneurship training } \\
\text { strengthens the effect of } \\
\text { resources on entrepreneurial } \\
\text { readiness }\left(\mathrm{H}_{7}\right)\end{array}$ & 0,168 & 0,156 & 0,023 & 0,041 \\
\hline
\end{tabular}




\begin{tabular}{lllll}
$\begin{array}{l}\text { Entrepreneurship training } \\
\text { strengthens the effect of } \\
\text { entrepreneurial ability on } \\
\text { entrepreneurial readiness }\left(\mathrm{H}_{8}\right)\end{array}$ & 0,152 & 0,139 & 0,013 & 0,001 \\
\hline
\end{tabular}

\section{Sources: Statistical Data Processing (2021)}

Based on the results of the partial test and the R Square value in the table above, equation 1 shows that: (1) Hypothesis one (H1) result from an R Square value of 0.089, a coefficient value of 0.368 , and a t-sig value of $0.000(0.000<0,05)$, which interpreted that motivation has a significant positive effect on entrepreneurial readiness, and the amount of effect is $8.9 \%$. (2) Hypothesis 2 (H2) result from an R Square value of 0.210, a coefficient value of 0.433 , and a t-sig value of $0.000(0.000<0.05)$, which interpreted that the opportunity identification has a significant positive effect on entrepreneurial readiness, and the amount of effect is $21 \%$. (3) Hypothesis 3 (H3) result from an $\mathrm{R}$ Square value of 0.215 , a coefficient value of 0.305 , and a t-sig value of $0.000(0.000$ $<0.05)$, which interpreted as having a significant positive effect on entrepreneurial readiness, and the amount of effect is $12.5 \%$. (4) Hypothesis four (H4) result from an $\mathrm{R}$ Square value of 0.076 , a coefficient value of 0.101 , and a $t$-sig value of $0.000(0.000$ $<0.05)$, which interpreted that entrepreneurial ability has a significant positive effect on entrepreneurial readiness, and the amount effect is $7.6 \%$.

Based on Table 3 above, it can also conclude that: (1) in equation 3 has a t-sig value of 0.723 (not significant), so it can conclude that entrepreneurship training can strengthen entrepreneurial readiness motivation, but the significance is weak, namely $3.7 \%$ (from equation 1 , which affects $8.9 \%$, and equation 3 becomes $12.6 \%$ ). (2) in equation 3 has a t-sig value of 0.007 (significant), so it can conclude that entrepreneurship training can strengthen opportunity identification on entrepreneurial readiness, which is $3.4 \%$ (from equation 1 , which affects $21 \%$, and equation 3 becomes 24.4\%). (3) in equation equation 3 has a t-sig value of 0.041 (significant), so it can conclude that entrepreneurship training can strengthen the effect of resources on entrepreneurial readiness, which is $4.3 \%$ (from equation 1, which affects $12.5 \%$, and equation 3 becomes 16.8\%). (4) in equation 3 has a t-sig value of 0.001 (significant), so it can conclude that entrepreneurship training can strengthen entrepreneurial skills' effect on entrepreneurial readiness by $7.6 \%$ (from equation 1 , which affects $7.6 \%$, and equation 3 becomes $15.2 \%$ ).

\section{The effect of motivation on entrepreneurial readiness}

The hypothesis testing results indicate that motivation has a positive and significant effect on entrepreneurial readiness. These results indicate that the higher the motivation, the higher the entrepreneurial readiness to start or run a business. This study's results are in accordance the opinion Vallerand (2004), which states that attitude and motivation have a reciprocal relationship and will show a behavioral tendency to achieve needs. If a person believes that the business he is going to or has carried out is very meaningful for him, he will strive for success. A person's 
motivation for entrepreneurship is to earn a profit, gain freedom in work, and be independent of himself and his business (Olugbola, 2017).

Entrepreneurial motivation is essential in shaping entrepreneurial readiness because it is a force that influences a person in carrying out an activity to achieve goals. High entrepreneurial motivation will also have a high impact on entrepreneurial readiness. This study's results are reinforced by previous research, which states that motivation positively and significantly affects entrepreneurial readiness (Kallas, 2019; Olugbola, 2017). Likewise, Jahn \& Geissler (2016) explain that entrepreneurial readiness forms by strong motivation, expectations of satisfaction, and environmental influences such as market conditions, business climate, technology, education, etc. Based on the explanation above, a conclusion made regarding this research results that an entrepreneur who has high motivation will form entrepreneurial readiness in himself to take action to achieve the desired goal. High entrepreneurial motivation will also have a high impact on entrepreneurial readiness

\section{The effect of opportunity identification on entrepreneurial readiness}

The hypothesis testing results indicate that opportunity identification has a positive and significant effect on entrepreneurial readiness. These results indicate that the higher the opportunity identification, the higher the Sukses Berkah Community (SBC) members' entrepreneurial readiness. One of the crucial factors that an entrepreneur must possess to achieve business success is identifying opportunities. Opportunity identification is needed to find and determine something that requires by the market. This identification of business opportunities must carry out continuously both before and when the business runs (Short et al., 2010).

Business opportunities are trends that are outside the business environment. If business actors can exploit them, these business opportunities have the potential to generate profits for the business on an ongoing basis (Kusmulyono, 2016). Everyone who has high sensitivity will find it easier to recognize market trends and identify business opportunities. Therefore it is necessary to have the ability to identify opportunities to form entrepreneurial readiness to support the achievement of business success. This study's results are reinforced by the results of previous studies, which state that opportunity identification has a positive and significant effect on entrepreneurial readiness (Khin \& Lim, 2018; Olugbola \& Kalsom, 2015). Likewise, research by Kirkley (2016) explains that technological advances, market opportunities, competition, consumer demand, and market conditions have a significant influence on readiness to create new businesses. Based on the explanation above, a conclusion made regarding this research results that before starting an entrepreneurial business, an entrepreneur must recognize and find hidden and developing opportunities to become a valuable business. Finding a business opportunity requires in-depth thought to be able to find the right business opportunity.

\section{The effect of resources on entrepreneurial readiness}


The hypothesis testing results indicate that resources has a positive and significant effect on entrepreneurial readiness. These results indicate that the higher the resources, the higher the Sukses Berkah Community (SBC) members' entrepreneurial readiness. Business resources are the input required by a business to carry out production activities. Resources play an essential role in creating a competitive product so that the product can compete in the market and improve business performance. Business success cannot separate from the use of resources in the production process, including physical resources, intellectual property, financial resources, and financial resources. The ability of entrepreneurs in managing business resources is one of the factors of business success (Vidayatmoko \& Rosadi, 2015).

Lack of resources owned in the business will hinder business development. So that resources are the main factor needed in setting up a business and often become obstacles. This study's results are reinforced by the results of previous studies, which state that resources have a positive and significant effect on entrepreneurial readiness (Seun \& Kalsom, 2015; Vuong et al., 2015). Research by Huang (2016) states that company resources affect business success. Likewise, research by Frid (2014) explains that a new business will be able to survive and develop its business if it has good resources. Based on the explanation above, a conclusion made regarding this research results that resources are an essential factor that a person must have in starting a business because good resources will and help him in developing a business and increasing business opinions so that it affects entrepreneurial readiness.

\section{The effect of enterprenurial ability on entrepreneurial readiness}

The hypothesis testing results indicate that entrepreneurial ability has a positive and significant effect on entrepreneurial readiness. These results indicate that the higher the entrepreneurial ability, the higher the Sukses Berkah Community (SBC) members' entrepreneurial readiness. Entrepreneurial ability will help entrepreneurs in making operational policies and determining strategic steps. Business success is influenced by the ability to plan, prepare budgets, formulate marketing strategies in providing attractive products, respond to environmental changes quickly, maintain relationships with customers, always improve product quality to achieve market share, and maintain a competent workforce (Agbim, 2013).

Before starting a business, one must have entrepreneurial skills. An entrepreneur in achieving business success must be skilled in using all his abilities and be creative at all levels to develop a business that is being run, such as technical skills, managerial skills, entrepreneurial skills, personal skills (Chang \& Rieple, 2013). This study's results are reinforced by the results of previous studies, which state that entrepreneurial ability has a positive and significant effect on entrepreneurial readiness (Acharya \& Chandra, 2019; Greene \& Saridakis, 2008; Seun \& Kalsom, 2015). Likewise, Chatterjee \& Das (2016) also shows that entrepreneurial ability affects entrepreneurial success. Based on the explanation above, a conclusion made regarding this research results that entrepreneurial ability is crucial for someone to start a new business. Not a few entrepreneurs fail due to planning and lack of entrepreneurial 
skills. One of the things to realize this business's success zis the personal attitude of an entrepreneur, namely a strong inner drive to do something using all his abilities.

\section{Entrepreneurship training strengthens motivation, opportunity identification, resources, and entrepreneurial ability on entrepreneurial readiness}

The hypothesis testing results show that entrepreneurship training can strengthen the influence of motivation on entrepreneurial readiness, but it is weak. These results indicate that the better the entrepreneurship training, the higher the motivation, thereby increasing entrepreneurial readiness. According to Mardetini et al. (2017) entrepreneurial motivation is not innate but through a process of education and experience. One form of entrepreneurship education is through entrepreneurship training. Entrepreneurship training will provide knowledge about entrepreneurship, form and improve skills, and increase relationships among entrepreneurs.

Entrepreneurship training is one of the strategic efforts to increase entrepreneurial motivation to support an increase in the number of entrepreneurs. This study's results are reinforced by the results of previous studies, which state that entrepreneurship training can strengthen the effect of motivation on entrepreneurial readiness (Olugbola \& Kalsom, 2015; Seun \& Kalsom, 2015). In line with other research results, which explains that entrepreneurship training can create new entrepreneurs because it can increase a person's motivation to start a business (Alam et al., 2019). Based on the explanation above, a conclusion made regarding this research results that entrepreneurship training has a significant influence on increasing one's motivation to start entrepreneurship because, through entrepreneurial training, one's potential, attitudes, and skills will form and developed.

The hypothesis testing results show that entrepreneurship training can strengthen the influence of opportunity identification on entrepreneurial readiness. These results indicate that the better the entrepreneurship training, the higher the opportunity identification, thereby increasing entrepreneurial readiness. Opportunity identification is one of the essential factors needed to start a business (Chang et al., 2014). However, not all entrepreneurs have the same way of identifying and finding opportunities. In this way, trained people will be more sensitive to market information, identify opportunities, and immediately turn them into businesses.

The ability to identify opportunities can learn by participating in entrepreneurship training, workshops that can play an essential role in increasing this ability (Fiet, 2007). This study's results are reinforced by the results of previous studies, which state that entrepreneurship training can enhance the effect of identifying opportunities on entrepreneurial readiness (Olugbola \& Kalsom, 2015). In line with other research results, which explains that entrepreneurship training can shape students' abilities in identifying business opportunities (Baggen et al., 2018; Costa et al., 2018). Based on the explanation above, a conclusion made regarding this research results that entrepreneurship training will provide opportunities and support someone to increase entrepreneurial readiness. Entrepreneurship training can increase 
a person's creativity and skills to form a mindset to generate business ideas and the ability to find solutions to business problems.

The hypothesis testing results show that entrepreneurship training can strengthen the influence of resources on entrepreneurial readiness. These results indicate that the better the entrepreneurship training, the higher the resources, thereby increasing entrepreneurial readiness. An entrepreneur has a role as a manager responsible for resource management (Suharyono, 2017). A business that can control the market is due to its ability to manage its resources. Resources owned by a company are essential to appropriately manage to increase maximum revenue and the products' competitive ability produced in market competition.

Entrepreneurial self-knowledge and abilities are needed so that they can manage their resources properly. Sumantri et al. (2013) explained that entrepreneurship training and education would encourage increased business income and expand the business marketing area. This study's results are reinforced by the results of previous studies, which state that entrepreneurship training can strengthen the effect of resources on entrepreneurial readiness (Greene \& Saridakis, 2008; Olugbola, 2017; Seun \& Kalsom, 2015). Likewise, research by Ahmed et al. (2020) explains that entrepreneurship education programs positively impact resource management to support them to start their businesses. Based on the explanation above, a conclusion made regarding this research results that entrepreneurship training plays a crucial role in improving the ability to manage and obtain business resources effectively and efficiently to achieve optimal goals. Resources are the input used by entrepreneurs to produce to play an essential role in achieving business success.

The hypothesis testing results show that entrepreneurship training can strengthen the influence of entrepreneurial ability on entrepreneurial readiness. These results indicate that the better the entrepreneurship training, the higher the entrepreneurial ability, thereby increasing entrepreneurial readiness. The entrepreneurial ability exists in an entrepreneur and is indispensable in starting a business and managing its business, such as management skills, financial management skills, marketing skills, the ability to formulate effective business planning, teambuilding skills, and administrative skills. A person obtains these abilities after attending training (Rusdin, 2017).

Entrepreneurship training will help increase insights and skills in entrepreneurship, and produce potential entrepreneurs who have the ability and can think critically, dare to face business challenges in running their business (Christanti, 2016). This study's results are reinforced by the results of previous studies, which state that entrepreneurship training can strengthen entrepreneurial skills' effect on entrepreneurial readiness (Ho et al., 2018; Leon, 2017). Likewise, research by Din et al., (2016) explains that entrepreneurship training activities can increase in knowledge and skills of training participants. Based on the explanation above, a conclusion made regarding this research results that by following the training, a person will gain and 
develop entrepreneurial skills that can support business success and continue to build and expand their knowledge. Entrepreneurship training will positively impact, namely shaping a person's ability, both soft-skills and hard-skills, to foster a confident attitude in running his business to achieve business success.

\section{Conclusion}

Based on the research results, a conclusion made that motivation, opportunity identification, resources, and entrepreneurial ability positively and significantly affect entrepreneurial readiness. Besides, entrepreneurship training can strengthen the effect of motivation on entrepreneurial readiness, but it is weak. However, entrepreneurship training significantly strengthens identification opportunity, resources and entrepreneurial abilities on entrepreneurial readiness. The better the entrepreneurship training carried out by Sukses Berkah Community (SBC) will affect to support the entrepreneurial readiness of its members. Trainers expected to provide more concrete pictures related to entrepreneurship motivate the emergence and increase members' interest and confidence to start entrepreneurship. SBC members can take advantage of the facilities provided to explore and develop their abilities and consult with trainers if they experience problems starting or running their business. The next researcher expected to determine other factors that can moderate the independent variable's influence on the dependent variable, namely, more specific entrepreneurial readiness. Different factors affect entrepreneurial readiness, such as entrepreneurial performance, government support, management information systems, individual characteristics, family background, and environment. The limitation of this research is that the research subject only on entrepreneurs who are members of the Sukses Berkah Community (SBC). Furthermore, the execution of this research during the Covid-19 pandemic, so implementation of entrepreneurship training online. The contribution of this research is used as a basis for improving the quality of entrepreneurship training in terms of materials, trainers, or training facilities for the Sukses Berkah Community(SBC).

\section{References}

Acharya, S. R., \& Chandra, Y. (2019). Entrepreneurship Skills Acquisition through Education: Impact of the Nurturance of Knowledge , Skills, and Attitude on New Venture Creation. International Journal of Education and Pedogogical Sciences, 13(2).

Agbim, K. C. (2013). The Relative Contribution of Management Skills to Entrepreneurial Success: A Survey of Small and Medium Enterprises (SMEs) in the Trade Sector. IOSR Journal of Business and Management, 7(1). https://doi.org/10.9790/487x-0710816

Ahmed, T., Chandran, V. G. R., Klobas, J. E., Liñán, F., \& Kokkalis, P. (2020). Entrepreneurship education programmes: How learning, inspiration and resources affect intentions for new venture creation in a developing economy. International Journal of Management Education. https://doi.org/10.1016/j.ijme.2019.100327

Alam, M. Z., Kousar, S., \& Rehman, C. A. (2019). Role of entrepreneurial motivation on entrepreneurial intentions and behaviour: theory of planned behaviour 
extension on engineering students in Pakistan. Journal of Global Entrepreneurship Research. https:/ / doi.org/10.1186/s40497-019-0175-1

Alma, B. (2011). Kewirausahaan. Rineka Cipta.

Badan Pusat Statistik. (2020). Berita Resmi Statistik. Bps.Go.Id. https://jakarta.bps.go.id/pressrelease/2019/11/01/375/tingkat-penghuniankamar--tpk--hotel--berbintang-dki-jakarta-pada-bulan-september-2019-mencapai58-97-persen.html

Baggen, Y., Kampen, J. K., Naia, A., Biemans, H. J. A., Lans, T., \& Mulder, M. (2018). Development and application of the opportunity identification competence assessment test (OICAT) in higher education. Innovations in Education and Teaching International. https://doi.org/10.1080/14703297.2017.1348962

Chang, J., \& Rieple, A. (2013). Assessing students' entrepreneurial skills development in live projects. Journal of Small Business and Enterprise Development, 20(1). https://doi.org/10.1108/14626001311298501

Chang, W. L., Liu, W. G. H., \& Chiang, S. M. (2014). A study of the relationship between entrepreneurship courses and opportunity identification: An empirical survey. Asia Pacific Management Review, 19(1). https:/ / doi.org/10.6126/APMR.2014.19.1.01

Chatterjee, N., \& Das, N. (2016). A Study on the Impact of Key Entrepreneurial Skills on Business Success of Indian Micro-entrepreneurs: A Case of Jharkhand Region. Global Business Review, 17(1). https://doi.org/10.1177/0972150915610729

Choo, S., \& Wong, M. (2006). Entrepreneurial intention: Triggers and barriers to new venture creations in Singapore. Singapore Management Review, 28(2).

Christanti, A. (2016). Studi Peranan Pelatihan Kewirausahaan Terhadap Pembentukan Sikap Dan Intensi Kewirausahaan Di Sentra Industri Produk Roti Dan Kue Rungkut Lor, Surabaya. Agora, 4(1).

Costa, S. F., Santos, S. C., Wach, D., \& Caetano, A. (2018). Recognizing Opportunities across Campus: The Effects of Cognitive Training and Entrepreneurial Passion on the Business Opportunity Prototype. Journal of Small Business Management, 56(1). https://doi.org/10.1111/jsbm.12348

Din, B. H., Anuar, A. R., \& Usman, M. (2016). The Effectiveness of the Entrepreneurship Education Program in Upgrading Entrepreneurial Skills among Public University Students. Procedia - Social and Behavioral Sciences, 224. https://doi.org/10.1016/j.sbspro.2016.05.413

Fiet, J. O. (2007). A prescriptive analysis of search and discovery. Journal of Management Studies, 44(4). https:/ / doi.org/10.1111/j.1467-6486.2006.00671.x

Fitriyanto, A. (2006). Ketidakpastian Memasuki Dunia Kerja karena Pendidikan. Rineka Cipta.

Frid, C. J. (2014). Acquiring financial resources to form new ventures: the impact of personal characteristics on organizational emergence. Journal of Small Business and Entrepreneurship, 27(3). https:/ / doi.org/10.1080/08276331.2015.1082895

Greene, F. J., \& Saridakis, G. (2008). The role of higher education skills and support in graduate self-employment. Studies in Higher Education, 33(6). https:/ / doi.org/10.1080/03075070802457082

Halim, H. A., Ahmad, N. H., Ramayah, T., \& Hanifah, H. M. (2017). Entrepreneurial 
readiness towards venture creation among bop community. International Journal of Entrepreneurship.

Hayton, J., Chandler, G. N., \& DeTienne, D. R. (2011). Entrepreneurial opportunity identification and new firm development processes: A comparison of family and non-family new ventures. International Journal of Entrepreneurship and Innovation Management. https://doi.org/10.1504/IJEIM.2011.038445

Ho, M. H. R., Uy, M. A., Kang, B. N. Y., \& Chan, K. Y. (2018). Impact of Entrepreneurship Training on Entrepreneurial Efficacy and Alertness among Adolescent Youth. Frontiers in Education. https://doi.org/10.3389/feduc.2018.00013

Huang, H. C. (2016). Entrepreneurial resources and speed of entrepreneurial success in an emerging market: the moderating effect of entrepreneurship. International Entrepreneurship and Management Journal. https://doi.org/10.1007/s11365-0140321-8

Hunter, M. (2013). A Typology Of Entrepreneurial Opportunity. Economics, Management, and Financial Markets, 8(2).

Jahn, S., \& Geissler, M. (2016). The motivational readiness model of entrepreneurship. 76th Annual Meeting of the Academy of Management, AOM 2016. https://doi.org/10.5465/AMBPP.2016.47

Kallas, E. (2019). Environment-Readiness Entrepreneurship Intention Model: The Case of Estonians and the Russian-Speaking Minority in Estonia. SAGE Open. https:/ / doi.org/10.1177/2158244018821759

Khin, S., \& Lim, T. H. (2018). Entrepreneurial opportunity recognition, exploitation and new venture success: Moderating role of prior market and technology knowledge. International Journal of Entrepreneurship.

Kirkley, W. W. (2016). Entrepreneurial behaviour: the role of values. International Journal of Entrepreneurial Behaviour and Research, 22(3), 290-328. https:// doi.org/10.1108/IJEBR-02-2015-0042

Kusmulyono, M. S. (2016). Peran Pengetahuan Pendahulu Dan Kepekaan Terhadap Kemampuan Mengidentifikasi Peluang Usaha Mikro Pedesaan. Jurnal Manajemen Maranatha, 16(1).

Leon, R. - D. (2017). Developing Entrepreneurial Skills. An Educational and Intercultural Perspective. Journal of Entrepreneurship, Management and Innovation, 13(2017). https://doi.org/10.7341/20171346

Lorena, S. (2018). Pengaruh Motivasi Dan Kemampuan Berwirausaha Terhadap Kinerja Usaha Pedagang Kaki Lima Di Kota Kraksaan. Manajemen Bisnis. https://doi.org/10.22219/jmb.v6i2.5544

Mardetini, E., Jaenudin, R., Fatimah, S., F, F., \& Eka Amrina, D. (2017). Peningkatan Pengetahuan dan Minat Berwirausaha Pada Industri Kreatif di Kecamatan Pemulutan Ogan Ilir. Jurnal Pemberdayaan Masyarakat Madani (JPMM), 1(2). https://doi.org/10.21009/jpmm.001.2.05

Oktiani, I. (2017). Kreativitas Guru dalam Meningkatkan Motivasi Belajar Peserta Didik. Jurnal Kependidikan. https://doi.org/10.24090/jk.v5i2.1939

Olugbola, S. A. (2017). Exploring entrepreneurial readiness of youth and startup success components: Entrepreneurship training as a moderator. Journal of 
Innovation and Knowledge, 2(3), 155-171. https:/ / doi.org/10.1016/j.jik.2016.12.004

Olugbola, S. A., \& Kalsom, A. W. (2015). Youth Entrepreneurship: Moderating Opportunity Identification towards New Venture Creation. International Journal of Review in Applied and Social Sciences.

Osterwalder, A., \& Pigneur, Y. (2012). Business Model Generation. PT Elex Media Komputindo.

Pandian, J. J. (2019). Entrepreneurial Training Effectiveness with Special Reference to District Industrial Centre, Thiruvallur. International Journal of Recent Technology and Engineering. https:// doi.org/10.35940/ijrte.d1054.1284s319

Pratomo, R. P. K., Mulyadi, H., \& Utama, D. H. (2018). Pengaruh Pembelajaran Kewirausahaan Terhadap Kesiapan Berwirausaha Siswa Kelas Xii Pastry Sekolah Menengah Kejuruan Negeri 9 Bandung. Journal of Business Management Education (JBME). https://doi.org/10.17509/jbme.v3i2.14216

Rusdin. (2017). Pendidikan dan Pelatihan Sebagai Sarana Peningkatan Kompetensi Guru di SMP Negeri 2 Linggang Bigung. Jurnal Administrative Reform, 5(4).

Saiman, L. (2009). Kewirausahaan, Teori, Praktik, dan Kasus-Kasus. Salemba Empat.

Seun, A. O., \& Kalsom, A. W. (2015). New venture creation determinant factors of social Muslimpreneurs. Pertanika Journal of Social Sciences and Humanities.

Short, J. C., Ketchen, D. J., Shook, C. L., \& Ireland, R. D. (2010). The concept of "Opportunity" in entrepreneurship research: Past accomplishments and future challenges. Journal of Management, 36(1). https://doi.org/10.1177/0149206309342746

Sitorus, E. (2015). Evaluasi Program Pelatihan Kewirausahaan Oleh Disnaker Kota Pekanbaru. Jurnal JOM FISIP, 2(2), 13.

Sudrajat. (2012). Kiat Mengentaskan Pengangguran dan Kemiskinan Melalui Wirausaha. Bumi Aksara.

Suharyono. (2017). Sikap Dan Perilaku Wirausahawan. Jurnal Ekonomi MODERNISASI, 10(1), 38.

Sukses Berkah Community. (2020). Official Website Sukses Berkah Community. https://suksesberkahcommunity.com/

Sumantri, B., Fariyanti, A., \& Winandi, R. (2013). Faktor-Faktor yang Berpengaruh terhadap Kinerja Usaha Wirausaha Wanita: Suatu Studi pada Industri Pangan Rumahan di Bogor. Jurnal Manajemen Teknologi, 12(3). https://doi.org/10.12695/jmt.2013.12.3.3

Vallerand, R. J. (2004). Intrinsic and Extrinsic Motivation in Sport. In Encyclopedia of Applied Psychology, Three-Volume Set. https://doi.org/10.1016/B0-12-6574103/00835-7

Vidayatmoko, D., \& Rosadi, A. H. R. (2015). Faktor Utama Kesuksesan Wirausaha di Industri Pangan. Jurnal Manajemen Teknologi, 14(1), 47-65. https://doi.org/10.12695/jmt.2015.14.1.4

Vuong, Q. H., Do, T. H., \& Vuong, T. T. (2015). Resources, experience, and perseverance in entrepreneurs' perceived likelihood of success in an emerging economy. Journal of Innovation and Entrepreneurship. https:/ / doi.org/10.1186/s13731-016-0047-7 